\title{
Fatty Acid Binding Protein 1 Measurement
}

National Cancer Institute

\section{Source}

National Cancer Institute. Fatty Acid Binding Protein 1 Measurement. NCI Thesaurus.

Code C82012.

The determination of the amount of fatty acid binding protein-1 present in a sample. 